\title{
CURRENT DIFFERENTIAL INFANTILE MORTALITY ENGLAND AND WALES
}

\author{
BY \\ WALLIS TAYLOR * \\ Department of Medical Statistics, University of Birmingham
}

A recent publication (Taylor, 1954) reviewed the decline of infantile mortality in England and Wales during the past half-century from a diagnostic viewpoint in as far as it is possible to do so by recourse to official sources. The outcome was a strong presumption in favour of the view that there is nolikelihood of stabilization at the present level, since the tempo of decline is still steep. One might be more confident about the long-range prospect if it were possible to speak with greater assurance about the local distribution of high rates, to what extent areas with high rates share common social characteristics, to what extent it is true that such areas have always had a high level of infant mortality, and to what extent inordinately high local infant death rates are associated with a single or few causes.

Official sources unfortunately supply too meagre data to answer these questions fully, even if we supplement information issued from the office of the Registrar-General with what we can learn from annual reports of Medical Officers of Health; and a deeper understanding of the present situation must await extensive ad hoc enquiries. Meanwhile, it may be useful to summarize what relevant figures are to hand as an indication for fruitful investigation in the field, more especially because the ONE per cent. sample of the 1951 Census supplies for the first time in 20 years a conspectus of the social characteristics of certain local areas. On that account the local unit of what follows is the population under the administration of a County Council.

The accompanying maps (Figs 1 and 2, overleaf) show that a high level of infantile mortality in 1935 was mainly located in the north and west. In 1952 the northerly concentration is less striking but in the west the infant death rate is still high. The history of localities with conspicuously high or conspicuously low rates as set forth in Table I discloses some striking regularities. That the absolute range has dropped from 77 (Dorset, 100; Lancashire, 177) in the quinquennium 1891-95 to 23 (Herts and East Sussex, 20; Montgomery and Westmorland, 43) in 1950 , tells only part of the story. If $h$ and $l$ stand for the highest and lowest rates referable to local units of

TABLE I

EXTREMES OF INFANT MORTALITY, 1876-1950, IN COUNTIES AND LARGE TOWNS

\begin{tabular}{|c|c|c|c|c|c|c|c|c|c|c|c|}
\hline \multirow{2}{*}{\multicolumn{2}{|c|}{$\begin{array}{l}\text { Year } \\
\text { Highest } \\
\text { Rates }\end{array}$}} & \multirow{2}{*}{$\begin{array}{l}\frac{1876-80}{2 \text { Leicestershire }} 169 \\
\text { Lancashire } \quad 165\end{array}$} & $1891-95$ & \multicolumn{2}{|l|}{$1901-05$} & \multicolumn{2}{|l|}{1910} & \multicolumn{2}{|l|}{1936} & \multicolumn{2}{|l|}{1950} \\
\hline & & & $\begin{array}{ll}\text { Lancashire } & 177 \\
\text { Glamorgan } & 173 \\
\text { Staffordshire } & 168 \\
\text { Leicestershire } & 167\end{array}$ & $\begin{array}{l}\text { Lancashire } \\
\text { Glamorgan } \\
\text { Durham }\end{array}$ & $\begin{array}{l}161 \\
158 \\
158\end{array}$ & $\begin{array}{l}\text { Carmarthen } \\
\text { Lancashire } \\
\text { Durham } \\
\text { Glamorgan }\end{array}$ & $\begin{array}{l}136 \\
129 \\
128 \\
126\end{array}$ & $\begin{array}{l}\text { Durham } \\
\text { Northumberland } \\
\text { Staffordshire } \\
\text { Denbigh } \\
\text { Caernarvon } \\
\text { Carmarthen } \\
\text { Glamorgan } \\
\text { West Riding } \\
\text { Yorkshire }\end{array}$ & $\begin{array}{l}71 \\
70 \\
67 \\
67 \\
66 \\
65 \\
63 \\
63\end{array}$ & $\begin{array}{l}\text { Montgomery } \\
\text { Westmorland } \\
\text { Durham } \\
\text { Glamorgan } \\
\text { Monmouth } \\
\text { Northumber- } \\
\text { land }\end{array}$ & $\begin{array}{l}43 \\
43 \\
40 \\
39 \\
39 \\
\\
36\end{array}$ \\
\hline $\begin{array}{l}\text { Lowest } \\
\text { Rates }\end{array}$ & & $\begin{array}{lr}\text { Wiltshire } & 108 \\
\text { Westmorland } & 107 \\
\text { Cardigan } & 99\end{array}$ & $\begin{array}{lr}\text { Westmorland } & 109 \\
\text { Wiltshire } & 103 \\
\text { Dorset } & 100\end{array}$ & $\begin{array}{l}\text { Dorset } \\
\text { Hertfordshire } \\
\text { Wiltshire }\end{array}$ & $\begin{array}{l}92 \\
92 \\
91\end{array}$ & $\begin{array}{l}\text { Wiltshire } \\
\text { Oxford } \\
\text { Hertfordshire }\end{array}$ & $\begin{array}{l}69 \\
67 \\
63\end{array}$ & $\begin{array}{l}\text { Hertfordshire } \\
\text { East Sussex } \\
\text { Cambridge } \\
\text { Wiltshire }\end{array}$ & $\begin{array}{l}38 \\
37 \\
37 \\
36\end{array}$ & $\begin{array}{l}\text { Wiltshire } \\
\text { Essex } \\
\text { Surrey } \\
\text { Middlesex } \\
\text { Cambridge } \\
\text { Oxford } \\
\text { Peterborough } \\
\text { (Soke of) } \\
\text { East Sussex } \\
\text { Hertfordshire }\end{array}$ & $\begin{array}{l}23 \\
23 \\
22 \\
22 \\
21 \\
21 \\
\\
20 \\
20 \\
20\end{array}$ \\
\hline Range & $\cdots$ & $\ldots 70$ & 77 & & 70 & & 73 & & 35 & & 23 \\
\hline \multicolumn{3}{|c|}{ Per cent. of Mean Range . . 52} & 56 & & 56 & & 73 & & 65 & & 73 \\
\hline
\end{tabular}




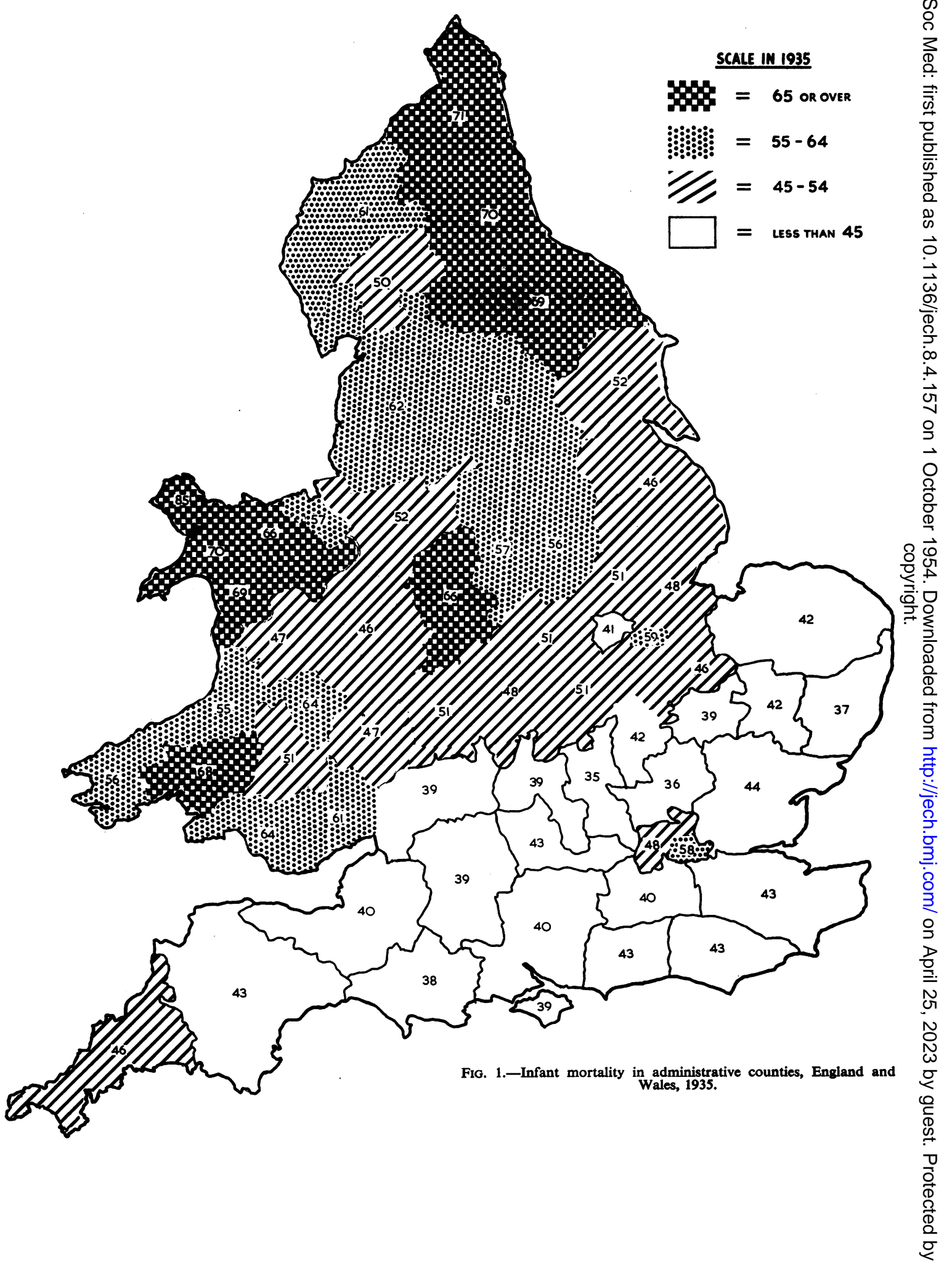




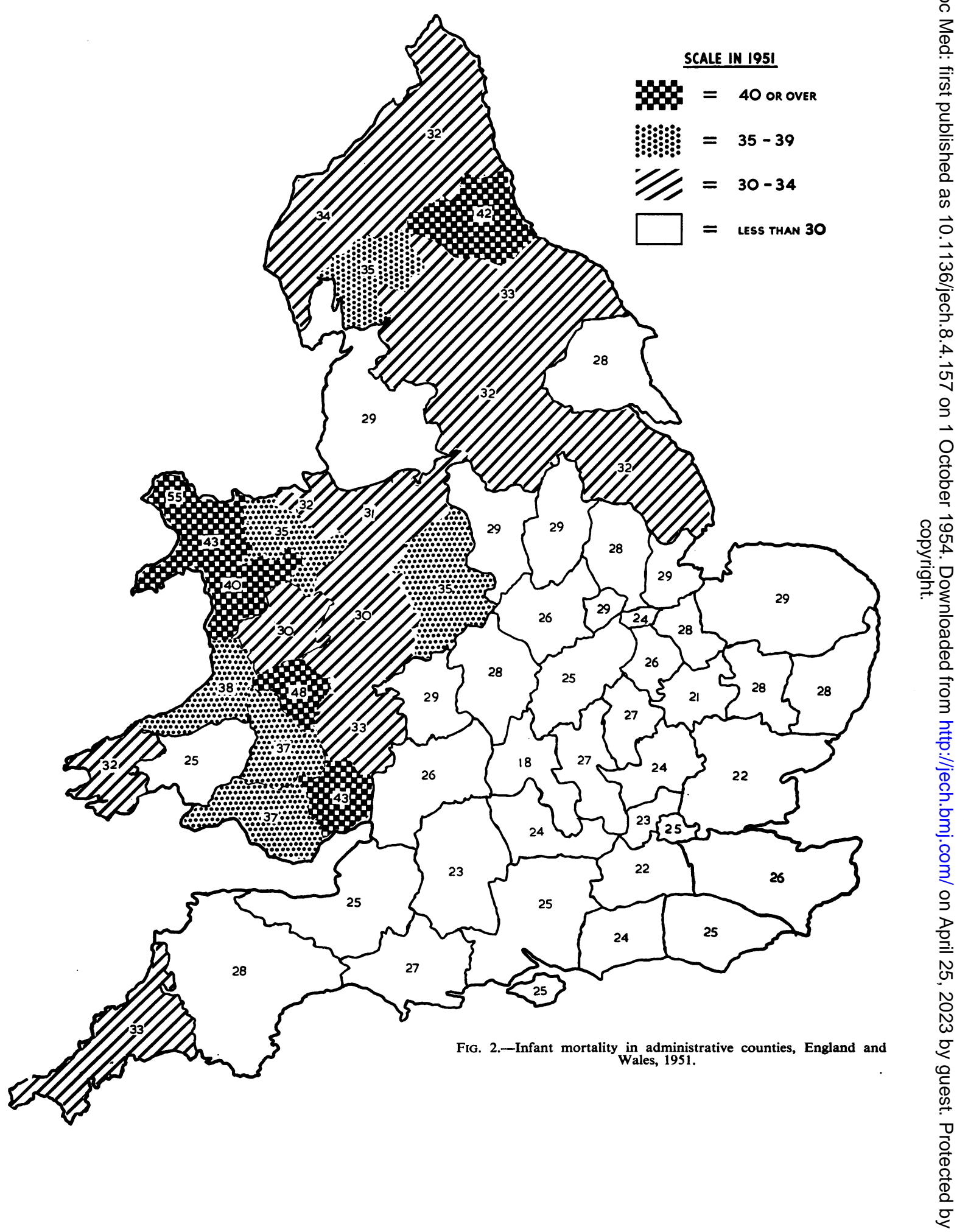


population in a given year or quinquennium, we may specify the range as a percentage of the mean, i.e. $100(h-l) \div \frac{1}{2}(h+l)$; and this has increased from 56 in the quinquennium 1891-95 to 73 in 1950.

Broadly, the data disclosed by Table I point to a high concentration in mining and quarrying regions and a low concentration in residential areas; but there are anomalies which provoke inquiry and defy any simple explanation in the light of data available. Thus Wiltshire has retained over half a century its place among population units with a very low level of infant death, but its population $(392,400$ in 1951) and the annual number of births (about 6,000 per annum at this time) are so small as to encourage the expectation that the infant death rate would be subject to wide fluctuations.

We may probe a little more deeply into the nature of these differences if we use a selected group of counties (Appendix) to which we can assign a current figure supplied by the 1951 Census for percentage of males employed in various occupations. Table II shows product-moment correlation coefficients referable to such percentages and to the infant death rate of the listed local units. The occupational picture which emerges indicates a striking association of high mortality with a high proportion of males engaged in mining or quarrying and of low mortality with a high proportion of black-coated or agricultural workers. Against the fact that a high proportion of persons engaged in personal services also goes with a low infant death rate, we should of course give due weight to the fact that such a concentration of individuals signifies a large body of residents able to pay for such services, whence a comparatively high level of material prosperity.

TABLE II

CORRELATION BETWEEN INFANT MORTALITY AND PERCENTAGE OF EMPLOYEES IN EACH OCCUPATIONAL GROUP, BY COUNTIES

\begin{tabular}{|c|c|c|c|}
\hline & $\begin{array}{c}\text { Occupational Group } \\
\text { (Standard Industrial Classification in brackets) }\end{array}$ & & $\boldsymbol{r}$ \\
\hline $\begin{array}{l}1 . \\
2 . \\
3 . \\
4 . \\
5 . \\
6 . \\
7 . \\
8 . \\
9 . \\
10 .\end{array}$ & $\begin{array}{l}\text { Mining and Quarrying (III) } \\
\text { Unskilled Occupations (XXVI) } \\
\text { Metal Manufacture and Engineering (VI) } \\
\text { Building and Contracting (XIV) .. } \quad . \\
\text { Textile Manufacture (VII) } \\
\text { Agriculture, Horticulture and Forestry (II) } \\
\text { Professional and Technical Occupations (XIX) } \\
\text { Personal Service (XXII) . . . } \\
\text { Administration, Directors, Managers (XVI) } \\
\text { Commerce, Finance, and Insurance (XVIII) }\end{array}$ & $\begin{array}{c}\cdots \\
\cdots \\
\cdots \\
\cdots \\
\cdots\end{array}$ & $\begin{array}{r}.724 \\
.459 \\
.153 \\
.086 \\
.061 \\
-.078 \\
-.471 \\
-\cdot .552 \\
-.566 \\
-\cdot .597\end{array}$ \\
\hline
\end{tabular}

That overcrowded homes and a low standard of parental education may be contributory to the higher infantile mortality rates invites us to invoke the technique of partial correlation. As a criterion of parents' educational standard, we employ the proportion of persons leaving full-time schooling before the age of 15 . Several indices of overcrowding may be computed from the 1951 Census data, inter alia:
(a) households per dwelling;
(b) rooms per household;
(c) persons per dwelling;
(d) persons per room;
(e) percentage households in unshared dwellings.

None of these is entirely satisfactory for our purpose, since size of room, number of rooms, and age-sex structure of the household are all relevant to a proper criterion of overcrowding. However, Charles (1951) noted that "in the City of Birmingham a very high proportion of babies were born to households with two or more persons per room", and "in a check survey on a very small randomly selected sample of households the standardized neonatal mortality rate rose according to degree of overcrowding". Thus she calculates:

\begin{tabular}{|c|c|c|c|}
\hline \multicolumn{3}{|c|}{ Persons per Room } & Standardized Neonatal \\
\hline $\begin{array}{l}\text { Less than } 1 \\
1 \text { and less than } 1 \cdot \dot{5} \\
1.5 \text { and less than } 2 \\
2 \text { or more }\end{array}$ & $\begin{array}{l}\cdots \\
\cdots \\
\cdots\end{array}$ & $\begin{array}{l}\cdots \\
\cdots \\
\cdots\end{array}$ & $\begin{array}{l}15 \cdot 8 \\
16 \cdot 0 \\
17 \cdot 2 \\
18 \cdot 3\end{array}$ \\
\hline
\end{tabular}

Accordingly, we have calculated the zero-order correlation between infant mortality and persons per room in shared dwellings as $r_{m h}=0.536$, which is very highly significant. It is known that a very high proportion of children are born into families sharing dwellings, so that this correlation is probably of high value as providing evidence that a major proportion of infant loss may be associated with overcrowded homes.

Table III (opposite) summarizes all we can infer concerning the interrelations of infantile mortality $(m)$, percentage of males engaged in mining and quarrying $(q)$, defective education specified above $(e)$, and the foregoing criterion of overcrowding (h). The zero-order correlations, $r_{m q}, r_{m e}$, and $r_{m h}$, between $m$ and $q, m$ and $e$, and $m$ and $h$, are all high; but so are those ( $r_{q h}$ and $\left.r_{q e}\right)$ between $q$ and $h$ or $e$. First-order partial coefficients other than $r_{m h . q}$ and $r_{m h . e}$ are fairly high, especially $r_{m q . h}$; the highest second-order coefficient is $r_{m q . h e}$. From this we may conclude that high infantile mortality associated with a high percentage of males employed in mining or quarrying is by no means largely attributable to the separate or joint effects of prevalent overcrowding, or of a low educational level characteristic of regions in which mining and quarrying are dominant occupations. Our sources do not permit us to explore the relevance of the wage level. Apart 
TABLE III

ZERO, FIRST, AND SECOND ORDER CORRELATION

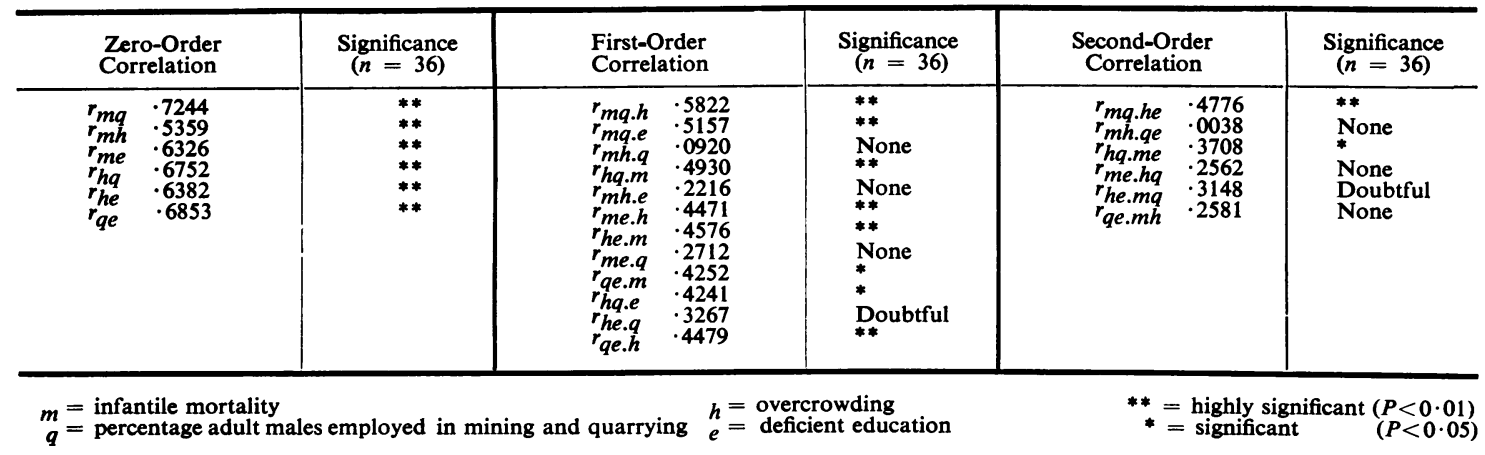

from the conclusion last stated, all that we can conclude by recourse to the new data made available from the 1951 Census ONE per cent. sample is that:

(a) Regional black-spots of infant mortality cannot be ascribed to a climate of locational causes.

(b) They are highly associated with the occupation of the males resident in these areas.

(c) The worst areas are of long-standing character.

(d) A poverty syndrome as depicted by Woolf and Waterhouse (1945) may still play a part.

It might be possible to learn more of the agencies contributing to the present tempo of decline, and hence to make short-term forecasts with some assurance, if all county medical health reports cited a diagnostic breakdown of infant deaths, comparable to what is available for the country as a whole through the annual reviews of the RegistrarGeneral.* Unfortunately, reports which do this are mostly referable to localities in which the rates are low, and an examination of material available seems to show that good records are available only for population units which have least need to profit from them. We can anticipate little further enlightenment without recourse to field enquiries on a costly scale.

Acknowledgements are due to Prof. Lancelot Hogben, F.R.S., for advice and assistance.

\section{REFERENCES}

Charles, E. (1951). British Journal of Social Medicine, 5, 41. Taylor, W. (1954). British Journal of Social and Preventive Medicine, $8,1$.

Woolf, B., and Waterhouse, J. (1945). J. Hyg. (Lond.), 44, 67.

* The county tables in the Registrar-General's reviews are not adequate for this purpose.
Bedfordshire

Berkshire

Buckinghamshire

Cheshire

Cornwall

Derbyshire

Devonshire

Dorset

Durham

\section{APPENDIX}

\section{Administrative County Areas used in Text}

Glamorganshire
Gloucestershire
Hertfordshire
Leicestershire
Lincolnshire (Lindsey)
Monmouthshire
Norfolk
Northamptonshire
Northumberland

Glamorganshire

Gloucestershire

Leicestershire

Monmouthshire

Northamptonshire

Northumberland
Nottinghamshire

Shropshire

Somerset

Southampton

Staffordshire

Sussex East

Sussex West

Warwickshire

Wiltshire
Worcestershire

Yorkshire (North Riding)

Essex

Kent

Lancashire

London

Middlesex

Surrey

Yorkshire (West Riding) 